\title{
FUTURE TEACHERS' CONCEPTIONS ON READING - A CASE STUDY
}

\author{
D. Melão \\ Escola Superior de Educação de Viseu, CI\&DEI, Instituto Politécnico de Viseu (PORTUGAL)
}

\begin{abstract}
In recent years, reading has been the focus of attention in Portugal, regarding the training of teachers. The implementation of the Portuguese National Teaching Program (2006-2010), the development of the National Reading Plan (in progress, until 2027) and other initiatives, at national level, namely concerning primary education, have contributed to innovate reading practices. However, despite the importance of these programs to make reading a priority of the Portuguese curriculum, few studies in Portugal investigate the conceptions on reading of future teachers' and their impact on educational practices, mainly regarding reading motivation and reading comprehension, recognized as increasingly relevant for the development of literacy.
\end{abstract}

The purpose of this study was twofold: to characterize and to identify the conceptions on reading of future teachers and to determine the influence of these conceptions on their future educational practices, concerning reading motivation and the development of competencies in reading comprehension. Participants were 53 future teachers enrolled in a first degree in Education (third year) of a polytechnic institute in the centre of Portugal. Considering the aims of this study, we took a qualitative approach, based on a case study framework. To increase the credibility and the reliability of the study, as recommended in the literature, several instruments were used to gather data: a questionnaire, a written essay and two worksheets for data on students' conceptions; a written report on lesson planning with individual and collective components, for data concerning students' competencies on reading comprehension.

Students' conceptions on reading emerged as a complex and multidimensional construct, mainly based on the valorisation of knowledge and vocabulary acquisition. Although most students enjoyed reading, due to both intrinsic and extrinsic motivation, they mostly valued it in classroom contexts and depreciated reading for pleasure, which was not the activity of their choice for their spare time. Conceptions on reading motivation were related mainly to family literacy practices, reading for academic purposes and reading habits (most students preferred to read novels, newspapers and magazines).

Results also showed that: i) when choosing books to motivate children to read, the importance of paratextual elements was strongly emphasized but students gave little attention to the importance of creating a literacy-rich environment in the classroom; ii) students had difficulties in establishing criteria to choose those books and to justify the choices they made as well. As far as students' competencies on reading comprehension were concerned, we concluded that they were mainly related to the strategies they were able to use while reading for different purposes. Important strategies such as activating prior knowledge and making inferences were not considered relevant by these students. Results on their lesson planning allowed us to understand that they replicated the reading strategies they used to develop children's reading comprehension.

We concluded that these conceptions on reading would have an impact on their future educational practices concerning reading motivation and the development of reading competencies. Further studies are needed for a deeper understanding of these conceptions, so that they might be considered on their training and have impact on their educational practices.

Keywords: Teaching, conceptions, reading motivation, reading comprehension.

\section{INTRODUCTION}

In recent years, reading literacy has been the focus of attention in Portugal, particularly regarding the training of teachers [1] [2]. At both national and international levels, strong emphasis has been put on the importance of the role of future teachers and teachers in the development of reading literacy, which is seen as a relevant factor for the development of global citizenship [3] [4]. 
The implementation of the Portuguese National Teaching Program (2006-2010), the development of the National Reading Plan (in progress, until 2027) and other initiatives, at national level, namely concerning primary education, have contributed to innovate reading practices. However, despite the importance of these programs to make reading a priority of the Portuguese curriculum, few studies in Portugal investigate the conceptions on reading of future teachers' and their impact on educational practices, mainly regarding reading motivation and reading comprehension.

In the light of the above, this study is guided by the following aims: to characterize and to identify the conceptions on reading of future teachers and to determine the influence of these conceptions on their future educational practices, concerning reading motivation and the development of competencies in reading comprehension.

\section{THEORETICAL FRAMEWORK}

There is a growing body of research focusing on the importance of characterizing higher education students' reading practices and reading literacy [5] [6] [7]. Research has also emphasized the relevance of identifying and characterizing university students' reading habits, for the implications in their academic performance [8]. Furthermore, studies focusing on higher education students' reading comprehension have unveiled weaknesses linked to poor choices of reading strategies, also stressing the difficulties they experienced during reading [9] [10].

Future teachers' conceptions on reading have also been receiving some attention, at international level [11] [12] [13], in studies aiming to shed light on their implications on future educational practices. Some studies have underlined possible links between weak reading experiences and difficulties in reading comprehension development, calling for intervention in future teachers' training, thus also recognizing the relevance of stronger literary education practices [14] [15].

Some studies regarding future teachers' reading performance have, in turn, showed that they mostly engage in the use of reading strategies while reading and after reading, seldom activating prior knowledge in the pre-reading stage [16] [17]. Other studies link variations in reading performance to text typologies/genres, stressing the need to implement strategies to diversify future teachers' reading habits, thus widening their knowledge about specific features characterizing different types of texts [18].

In Portugal, although several curriculum reforms are under way, and reading literacy has become a major national concern, research regarding future teachers' conceptions on reading and their impact on educational practices is still scarce. This study aims to contribute to fill this gap, thus also bringing to light the need to pursue new avenues of research concerning future teachers' training.

\section{METHODOLOGY}

The following research questions $(R Q)$ guided data collection and analysis:

- $\mathrm{RQ} 1$ What are future teachers' conceptions on reading?

- RQ 2 How might these conceptions influence their future educational practices encompassing reading motivation and the development of competencies in reading comprehension?

This study employed a qualitative single case study research approach. The case study method has been increasingly used in Education, despite traditional concerns regarding its limitations. The choice of the case study was guided by the aims of our study, that is, to identify and characterize future teachers' conceptions on reading, giving the importance of "how" they would manifest themselves and "why" - due to the implications for their future practices concerning reading motivation and reading comprehension development. A case study protocol was designed, following Yin's proposal [19], in order to increase the validity of the study, thus mitigating limitations.

\subsection{Participants}

Participants were 53 3rd year students enrolled in a first degree in Education of a Polytechnic Institute, in Portugal. Students ages ranged mainly between 20 and 21 years old $(35,8 \%$ and $24,5 \%$, respectively), the majority of whom were female (94\%) and had low socio-cultural backgrounds. Previously, in secondary education, they had attended courses of Scientific-Humanistic nature $(77 \%)$, mainly in the area of Sciences and Technology. 


\subsection{Data collection tools}

To increase the credibility and the reliability of the study, several instruments were used to gather data, as recommended: a questionnaire $(\mathrm{Q})$, a written essay (WE) and two worksheets for data on students' conceptions (W); a written report (WR) on lesson planning with individual and collective components, for data concerning students' competencies on reading comprehension.

The questionnaire included 32 questions, of which 17 were open (aiming at collecting richer and more diversified data). It was applied first, in order to collect information on the personal data of the students (section one), their previous academic background (section two) and their conceptions on reading (section three). Before its application, a pre-test was carried out, with a reduced number of students, in order to identify the need to make changes that would contribute to its improvement. In order to guarantee scientific rigor and to improve any existing gaps, the questionnaire was evaluated by two Didactics specialists, as recommended. For the purpose of this paper, our focus will be on the questions regarding, specifically, future teachers' conceptions on reading and their reading habits.

In order to complement the information about future teachers' conceptions on reading, two worksheets were applied at the beginning and the end of the semester, so that we could infer if their conceptions on reading had changed. In both they were asked to indicate: i) which four words they associated to the concept of reading (from the most important to the least important); ii) how they envisaged their future pupils' as readers; iii) how they would plan to motivate their future pupils' to read; iv) how they would plan to develop their future pupils' reading comprehension. For the purpose of this paper, these data are not included.

The written essay encompassed a through description of the paths taken by the students to choose of a book in the format they preferred (printed or digital) that they could later use for lesson planning aiming at reading motivation and reading comprehension development.

The written report (with a group component and an individual component) was carried out at the end of the semester, in order to allow students a more in-depth reflection on the requested activity planning.

Triangulation of data collected aimed to promote a deeper understanding of our object of study (a recommended step regarding the validity of the construct concerning case studies [20]).

\subsection{Research techniques}

The privileged technique was content analysis that we combined with descriptive statistics (relative and absolute frequencies). Content analysis was performed following Bardin's steps [21] (2004) and involved a process of coding statements from the open questions of the questionnaire, the questions of both worksheets, the written essay and the written report. The latter categories were defined a priori, based on a theoretical framework of didactic strategies to develop reading comprehension [22]. In both cases, the number of frequencies recorded was considered as an additional element of reflection, regarding our object of study.

\section{RESULTS AND DISCUSSION}

\subsection{Conceptions on reading and reading habits}

In the section of the questionnaire devoted to reading (section three), we started by asking future teachers if they liked to read. Most of future teachers (81\%) answered affirmatively; some of them, however, gave a negative answer (19\%), either because of lack of interest in reading or the absence of reading habits at home.

The content analysis results that emerged from future teachers' answers, regarding their reasons for enjoying reading, are displayed in Table 1 : 
Table 1. Reasons for enjoying reading, according to future teachers

\begin{tabular}{l|c|c}
\hline \multicolumn{1}{c|}{ Categories } & Freq. & $\%$ \\
\hline Acquiring knowledge/Vocabulary & 22 & $37 \%$ \\
\hline Escape from reality & 18 & $32 \%$ \\
\hline Recreational purposes & 6 & $10 \%$ \\
\hline Improvement of reading/writing/speaking skills & 3 & $5 \%$ \\
\hline Creativity/imagination development & 3 & $5 \%$ \\
\hline Citizenship & 2 & $3 \%$ \\
\hline Intrinsic motivation & 2 & $3 \%$ \\
\hline Extrinsic motivation & 1 & $2 \%$ \\
\hline Null answers & 2 & $3 \%$ \\
\hline Total & 59 & $100 \%$ \\
\hline \hline
\end{tabular}

Table 1 shows students' preference for reading mainly as a way of «Acquiring knowledge/vocabulary» $(37 \%)$, as well as «Escape from reality» $(32 \%)$. These results corroborate two of the most given justifications by higher education students regarding their reading practices [14] [15]. Only a few students acknowledged they read for «Recreational purposes» $(6 \%)$, «Improvement of their reading/writing/speaking skills» (5\%) or "Creativity/imagination development» (5\%). Intrinsic motivation $(3 \%)$ was highly underestimated. Students who mentioned it, revealed, however, their passion for reading, envisaging it as a commitment for life: «It's something that I cannot explain I have been enjoying reading since I learned to read. I am what I am very much for what I read» (Q3) «Because I always enjoyed it, it's a part of me» (Q5).

Table 2 displays the results regarding sources of reading incentives, according to future teachers:

Table 2. Sources of reading incentives, according to future teachers

\begin{tabular}{c|c|c|c|c|c|c|c|c|c}
\hline \hline \multirow{2}{*}{ Answer } & \multicolumn{2}{|c|}{ Frequently } & \multicolumn{2}{c|}{ Occasionally } & \multicolumn{2}{c|}{ Seldom } & \multicolumn{2}{|c|}{ Never } & \multirow{2}{*}{ Total } \\
\cline { 2 - 10 } & Freq. & $\%$ & Freq. & $\%$ & Freq. & $\%$ & Freq. & $\%$ & \\
\hline Father & 5 & $12 \%$ & 12 & $30 \%$ & 22 & $55 \%$ & 1 & $3 \%$ & $40-100 \%$ \\
\hline Mother & 23 & $57 \%$ & 11 & $27 \%$ & 5 & $13 \%$ & 1 & $3 \%$ & $40-100 \%$ \\
\hline Brothers/Sisters & 15 & $37 \%$ & 11 & $28 \%$ & 6 & $15 \%$ & 8 & $20 \%$ & $40-100 \%$ \\
\hline Grandparents & 1 & $3 \%$ & 9 & $22 \%$ & 13 & $33 \%$ & 17 & $42 \%$ & $40-100 \%$ \\
\hline Other relatives & 5 & $12 \%$ & 16 & $40 \%$ & 12 & $30 \%$ & 7 & $18 \%$ & $40-100 \%$ \\
\hline Teachers & 23 & $57 \%$ & 14 & $35 \%$ & 3 & $8 \%$ & 0 & $0 \%$ & $40-100 \%$ \\
\hline Friends & 4 & $10 \%$ & 0 & $0 \%$ & 36 & $90 \%$ & 0 & $0 \%$ & $40-100 \%$ \\
\hline Others & 0 & $0 \%$ & 0 & $0 \%$ & 0 & $0 \%$ & 0 & $0 \%$ & 0 \\
\hline \hline
\end{tabular}

Table 2 highlights that future teachers received reading incentives from their «Teachers» frequently $(57 \%)$, as well as from their «Mother» $(57 \%)$. «Brothers/sisters» seemed to have played an important role, frequently too $(37 \%)$. According to future teachers, their "Grandparents» and their "Father» contributed less to foster their reading engagement. «Friends» did not seem to have had a positive influence to increase their interest in reading. Despite todays' family's diversity, mothers appear to be, in this case, the strongest influence regarding reading incentives. Home literacy environment has long been recognised as one of the key factors to foster young children's emergent literacy [23] and the mother's level of education has been related to children's learning [24].

Asked about their reading preferences, students stated that they enjoyed mostly novels (38\%) and, cumulatively, newspapers and magazines (28\%). Biographies (7,5\%), "adventure books" $(7,5 \%)$, "children's books" (3,8\%) and "comic books" (3,8\%) were not as popular. The "scientific articles" 
$(4,5 \%)$ and the "articles on the internet" $(3,8 \%)$ should also be highlighted, for the lesser emphasis they gave them (perhaps because they link this type of reading with academic purposes, as an obligation).

The preference for reading novels is commonly pointed out by higher education students, including future teachers, and newspapers and magazines are also mentioned in some studies of similar character [25] [26].

The results concerning purposes for reading and their frequency, as acknowledged by future teachers, are shown in Table 3:

Table 3. Purposes for reading and their frequency

\begin{tabular}{l|c|c|c|c|c|c}
\hline \hline Purposes for reading & Daily & $\begin{array}{c}\text { Two to three } \\
\text { times a week }\end{array}$ & $\begin{array}{c}\text { During the } \\
\text { weekend }\end{array}$ & $\begin{array}{c}\text { Once or twice } \\
\text { a month }\end{array}$ & $\begin{array}{c}\text { Once or twice } \\
\text { a year }\end{array}$ & Total \\
\hline $\begin{array}{l}\text { Reading for } \\
\text { recreational purposes }\end{array}$ & $8-15 \%$ & $8-15 \%$ & $20-38 \%$ & $10-19 \%$ & $7-13 \%$ & $53-100 \%$ \\
\hline $\begin{array}{l}\text { Reading for academic } \\
\text { purposes }\end{array}$ & $29-55 \%$ & $20-38 \%$ & $4-7 \%$ & $0-0 \%$ & $0-0 \%$ & $53-100 \%$ \\
\hline $\begin{array}{l}\text { Reading for } \\
\text { informational purposes }\end{array}$ & $22-41 \%$ & $21-40 \%$ & $8-15 \%$ & $2-4 \%$ & $0-0 \%$ & $53-100 \%$ \\
\hline \hline
\end{tabular}

Table 3 highlights that these future teachers read mainly daily for academic (55\%) and for informational purposes $(41 \%)$. Understandably, recreational reading would take place mainly during the weekend $(38 \%)$, on their spare time. However, some of these future teachers acknowledged they read for recreational purposes once or twice a month (19\%) and others once or twice a year $(13 \%)$. Although most of them had admitted enjoying reading, these results corroborate the justifications given before, regarding their enjoyment to engage in this activity (Table 1).

\subsection{Reading motivation and reading comprehension}

The content analysis performed, regarding the written essay (WE), which encompassed a through description of the paths taken by the students to choose a book in the format they preferred (printed or digital) that they could later use for lesson planning aiming at reading motivation and reading comprehension development, sheds light on their reading motivation. All future teachers chose narratives.

Categories and subcategories that emerged from future teachers answers, concerning the criteria they used when choosing books to motivate children to read, are displayed in Table 4:

Table 4. Criteria used by future teachers to choose books to motivate children to read

\begin{tabular}{l|l|c|c|c|c}
\hline \hline Categories & \multicolumn{1}{|c|}{ Subcategories } & Freq. & $\%$ & Total & $\%$ \\
\hline \multirow{2}{*}{$\begin{array}{l}\text { Textual } \\
\text { features }\end{array}$} & Topic & 12 & $21,1 \%$ & & \\
\cline { 2 - 4 } & Text extension & 7 & $12,3 \%$ & \multirow{2}{*}{25} & \multirow{2}{*}{$43,9 \%$} \\
\cline { 2 - 4 } & Vocabulary & 5 & $8,8 \%$ & & \\
\cline { 2 - 4 } & Genre/type of text & 1 & $1,8 \%$ & & \\
\hline \multirow{2}{*}{$\begin{array}{l}\text { Paratextual } \\
\text { features }\end{array}$} & Illustrations & 19 & $33,3 \%$ & & \multirow{2}{*}{32} \\
\cline { 2 - 4 } & Title & 11 & $19,3 \%$ & $56,1 \%$ \\
\cline { 2 - 4 } & Font size & 2 & $3,5 \%$ & & \\
\hline Total & & 57 & $100 \%$ & 57 & $100 \%$ \\
\hline \hline
\end{tabular}

Table 4 shows that the category «Paratextual features» $(56,1 \%)$ was the most highlighted by these future teachers, followed by "Textual features» $(43,9 \%)$. As far as paratextual features were 
concerned, the subcategory «lllustrations» received great attention (33,3\%); lesser emphasis was given to the «Title» $(19,3 \%)$ and, mainly, to the «Font size» $(3,5 \%)$.

As far as illustrations are concerned, future teachers enthusiasm' emerged, for example, in the following statements: "The illustrations invite the child to be more enthusiastic about reading, as well as to draw inferences about what he/she has read, because these are usually very representative of the text that goes along with them» (E22) / "One of the reasons that also made me choose this book (...) was the fact that it has excellent illustrations, because in this age group (2nd year) children associate the images very much with what they are told» (E50). Both statements corroborate contemporary research about the increasingly important role of illustration to foster reading engagement as well as reading comprehension [27] [28].

The "Topic» was the most emphasized subcategory $(21,1 \%)$ within the category «Textual features». One of the future teachers mentioned, for example, the following: «Manuel Antonio Pina's "The Treasure" is stimulating (I read it twice) because of its topic - it talks about the value of freedom as a treasure, becoming important for children to realize its importance» (E15). In this statement emerges not only the student's strong interest in the above-mentioned book but also her concern for instilling an active exercise of citizenship in her future pupils. It is widely recognized that the topic of a book to which children can relate to helps to increase their interest in reading, as well to promoting their curiosity [29].

Future teachers considered «Text extension» $(12,3 \%)$ less relevant to foster reading engagement. Those who mentioned it stressed the importance of choosing shorter texts, aimed at children's interests and reading pace, in order to nurture a love of reading.

The content analysis of the written reports (WR) that future teachers delivered at the end of the semester allowed us a more in-depth analysis of their didactic performance concerning the development of reading comprehension skills. As described before (3.2.), this written report consisted of two parts: an individual part and another one concerning group work. Future teachers were gathered in groups of three to four elements (14 groups, in total) and each group delivered a lesson plan.

The categories that emerged regarding reading strategies encompassed in future teachers' lesson planning for primary education are displayed in Table 5:

Table 5. Reading strategies chosen by future teachers' in their lesson plans

\begin{tabular}{|c|c|c|c|c|c|}
\hline Categories & Subcategories & Freq. & $\%$ & Total & $\%$ \\
\hline \multirow[t]{3}{*}{ Pre-reading } & Activating prior knowledge & 3 & $5,4 \%$ & \multirow{3}{*}{14} & \multirow{3}{*}{$25 \%$} \\
\hline & Making predictions & 10 & $17,9 \%$ & & \\
\hline & Asking questions about the text & 1 & $1,8 \%$ & & \\
\hline \multirow[t]{4}{*}{ Reading } & Reading the text carefully & 12 & $21,4 \%$ & \multirow{4}{*}{19} & \multirow{4}{*}{$33,9 \%$} \\
\hline & Underlining & 3 & $5,4 \%$ & & \\
\hline & Confirming/adjusting predictions made before reading & 3 & $5,4 \%$ & & \\
\hline & Making inferences & 1 & $1,8 \%$ & & \\
\hline \multirow[t]{5}{*}{ Post-reading } & Rereading & 5 & $8,9 \%$ & \multirow{5}{*}{23} & \multirow{5}{*}{$41,1 \%$} \\
\hline & Identifying the main ideas of the text & 12 & $21,4 \%$ & & \\
\hline & Using dictionaries to look up the meanings of words & 4 & $7,1 \%$ & & \\
\hline & Online searching & 1 & $1,8 \%$ & & \\
\hline & Identifying genre/type of text & 1 & $1,8 \%$ & & \\
\hline Total & & 56 & $100 \%$ & 56 & $100 \%$ \\
\hline
\end{tabular}

Table 5 shows that «Post-reading» $(41,1 \%)$ was the category that stood out, followed by the categories «Reading» $(33,9 \%)$ and «Pre-reading» $(25 \%)$.

Within «Post-reading», the subcategory «Identifying the main ideas of the text» $(21,4 \%)$ was highlighted in future teachers' lesson plans. One of the reasons that might explain this choice is the fact that textbooks, in Portugal, as far as reading comprehension is concerned, give greater emphasis 
to the identification of the main ideas of the text, rather than proposing activities that encompass the use of multiple strategies, one of the features that characterizes «good readers» [30] [31].

Although its importance for offering pupils the opportunity to discover features of the texts that went unnoticed during initial reading [32], «Rereading» $(8,9 \%)$ was not greatly emphasized by future teachers in their lesson plans.

«Using dictionaries to look up the meanings of words» $(7,1 \%)$, «Online searching» $(1,8 \%)$ and «Identifying genre/type of text» $(1,8 \%)$ were hardly mentioned in future teachers' lesson plans. The importance of using dictionaries for monitoring comprehension has been emphasized [33] [34] and its association with the development of strategies aimed at clarifying vocabulary has also been acknowledged [35]. The identification of the type of text read, in turn, helps learners to familiarize themselves with the specific structure of each textual typology [36] [37]. However, only one group who proposed to approach a narrative text in their lesson planning considered that it was relevant. As far as "Online searching" is concerned, it was related to a proposal to deepen one of the topics addressed in the narrative text chosen by one of the groups.

The category "Reading» was also highlighted in future teachers' lesson plans. "Reading the text carefully» $(21,4 \%)$ was considered particularly important. «Underlining» $(5,4 \%)$, «Confirming/adjusting predictions made before reading» $(5,4 \%)$ and "Making inferences» $(1,8 \%)$ were considered less relevant by future teachers. However, the advantages associated with making inferences during reading have been widely recognized [38] and confirming/adjusting predictions made before reading has been reported to help learners to become more efficient readers [39].

«Pre-reading» was less emphasized (25\%), despite the major role that plays to foster reading engagement. «Making predictions» $(17,9 \%)$ stood out while «Activating prior knowledge $(5,4 \%)$ and «Asking questions about the text» $(1,8 \%)$ were devalued. Research has shown that readers with strong comprehension actively draw upon their prior knowledge [40]; by overlooking it in their lesson plans, these future teachers appear to be unaware of its major importance, which deserves, perhaps, further attention in their training. As Wigfield, Gladstone and Turci (2016) put it, "Teachers with extensive knowledge of the most effective reading strategies with which to instruct their children will only be successful to the extent that their students are motivated to learn and use those strategies» [41]. Future teachers' training should, therefore, give them the tools to achieve this goal.

\section{CONCLUSIONS}

This paper intended to shed some light on future teachers' conceptions on reading and how they might influence their future educational practices concerning reading motivation and the development of competencies in reading comprehension, addressing a Portuguese context.

Future teachers' conceptions on reading emerged as a complex and multidimensional construct, mainly based on the valorisation of knowledge and vocabulary acquisition. Although most of them enjoyed reading, due to both intrinsic and extrinsic motivation, they valued it in classroom contexts and underestimated reading for pleasure. Conceptions on reading motivation were related mainly to family literacy practices, reading for academic purposes and reading habits (most future teachers preferred to read novels, newspapers and magazines).

Results also showed that: i) when choosing books to motivate children to read, the importance of paratextual elements was strongly emphasized but future teachers gave little attention to the importance of creating a literacy-rich environment in the classroom; ii) future teachers had difficulties in establishing criteria to choose those books and to justify the choices they made as well. As far as future teachers' competencies on reading comprehension were concerned, we concluded that they were mainly related to the strategies they were able to use while reading for different purposes. Important strategies such as activating prior knowledge and making inferences were not considered relevant by these future teachers.

We concluded that future teachers' conceptions on reading would have an impact on their future educational practices concerning reading motivation and the development of reading competencies. Further studies are needed for a deeper understanding of these conceptions, so that they might be considered on their training and have impact on their educational practices. 


\section{REFERENCES}

[1] H. Buescu, J. Morais, M. R. Rocha and V. M. Magalhães, Programa e metas curriculares de Português do ensino básico. Lisboa: Direção-Geral da Educação, 2015.

[2] Ministério da Educação. Aprendizagens essenciais. Português, $2 .^{\circ}$ ano. Lisboa: Ministério da Educação, 2018.

[3] C. M. Sá, Flexibilidade curricular e perfil do aluno para o século XXI. Educação e Formação Cadernos Didáticos, no. 3. Aveiro: Universidade de Aveiro, 2019.

[4] European Commission/EACEA/Eurydice. Citizenship education at school in Europe - 2017. Eurydice Report. Luxembourg: Publications Office of the European Union, 2017.

[5] A. T. Perdigón. "Leer y escribir en la universidad: una experiencia desde una concepción no instrumental." Estudios Pedagógicos, no.1 (43), 2017. Retrieved from https://scielo.conicyt.cl/scielo.php?script=sci_arttext\&pid=S0718-07052017000100018

[6] S. Yubero, E. Larrañaga and N. Pires, Estudo sobre os hábitos de leitura dos estudantes portugueses do ensino superior. Castelo Branco: Edições IPCB, 2014.

[7] D. Melão, A. I. Silva and J. P. Balula. "Representações da leitura de futuros educadores sociais - um estudo de caso." Indagatio Didactica, no.10 (5), 111-127, 2018. Retrieved from http://revistas.ua.pt/index.php/ID/article/view/11621/9536

[8] K. L. Oliveira. "Considerações acerca da compreensão em leitura no ensino superior," Psicologia: Ciência e Profissão, no. 4 (31) pp. 690-701, 2011. Retrieved from http://www.scielo.br/scielo.php?script=sci_arttext\&pid=S141498932011000400003A.A.

[9] A. P. Cabral and J. Tavares. "Leitura/compreensão escrita e sucesso académico: um estudo de diagnóstico em quatro universidades Portuguesas." Psicologia Escolar e Educacional, no.9 (2), 203-213, 2005. Retrieved from

http://www.scielo.br/scielo.php?pid=\$141385572005000200003\&script=sci_arttext

[10] M. C. Andrade Calderón. "La lectura en los universitarios. Un caso específico: Universidad Colegio Mayor de Cundinamarca." Tabula Rasa, 7, 231-250, 2007. Retrieved from http://www.redalyc.org/articulo.oa?id=39600711

[11] G. Ghiggi, P. M. Chaves and R. N. Silva. A formação de leitores assumida como proposta pedagógica: das contradições às congruências. Leitura: Teoria \& Prática, no.35 (69), 115-130, 2017. Retrieved from https://tp.emnuvens.com.br/ltp/article/view/563

[12] J. A. Caride, M. B. Caballo and R. Gradaílle. "Leer en tiempos de ocio: los estudiantes, futuros profesionales de la educación, como sujetos lectores." Ocnos, no.17 (3), 7-18, 2018. doi: https://doi.org/10.18239/ocnos_2018.17.3.1707

[13] M. E. Larrañaga and S. Yubero. La compleja relación de los docentes con la lectura: el comportamiento lector del profesorado de educación infantil y primaria en formación. Bordón. Revista de Pedagogía, no.71 (1), 31-45, 2019. doi: 10.13042/Bordon.2019.66083

[14] C. Granado. El docente como lector: estudio de los hábitos lectores de futuros maestros. Cultura y Educación, no.26, (1), 44-70, 2014. doi: 10.1080/11356405.2014.908666

[15] D. M. L. L. Saldanha and M. Amarilha. Literatura e formação do pedagogo: caminhos que (ainda) não se cruzam. Desenredo, no. 2 (12), 376-396, 2016. Retrieved from http://seer.upf.br/index.php/rd/article/view/6389/4055

[16] D. G. Gimenes and E. M. M. P. Pullin. Estratégias de leitura utilizadas por licenciandos de áreas distintas para lerem textos de estudo. Semina: Ciências Sociais e Humanas, no.31, (1), 111-122, 2010. doi: 10.5433/1679-0383.2010v31n1p111

[17] M. C. T. Vieira. Os futuros professores e as estratégias de compreensão leitora. Revista Eletrônica Pesquiseduca, no.4, (2), 209-229, 2010. Retrieved from http://periodicos.unisantos.br/index.php/pesquiseduca/article/view/106

[18] A. C. M. Fuentes, P. S. Rubilar and F. R. Alveal. Comprensión lectora en la formación inicial docente: estudiantes de educación general básica en una universidad del consejo de rectores. Folios, no.35, 33-47, 2012. Disponível em http://www.scielo.org.co/scielo.php?pid=S012348702012000100003\&script=sci_arttext 
[19] R. K. Yin. Case study research: design and methods, 5th edition, 2013. Thousand Oaks: Sage.

[20] R. Bogdan and S. Biklen. Investigação qualitativa em educação. Porto: Porto Editora, 1994.

[21] L. Bardin. Análise de conteúdo. Lisboa: Edições 70, 2004.

[22] C. M. Sá. Estratégias didáticas para o ensino explícito da compreensão na leitura. Aveiro: Universidade de Aveiro/Departamento de Didática e Tecnologia Educativa, 2009.

[23] N. Saracho. "Research, policy, and practice in early childhood literacy," Early Child Development and Care, no. 3-4 (187) 305-321, 2017. doi: 10.1080/03004430.2016.1261512

[24] B. Muñoz and A. Anwandter. Manual de lectura temprana compartida: ¿por qué es importante y cómo ler com niños y niñas de 0 a 7 años? Chile: Consejo Nacional de la Cultura y las Artes/Fondo Nacional de Fomento del Libro y la Lectura, 2011.

[25] S. Annamalai, S. and B. Muniandy. Reading habit and attitude among Malaysian polytechnic students. International Online Journal of Educational Sciences, no.5 (1), 32-41, 2013. Retrieved from http://www.iojes.net/userfiles/article/iojes_946.pdf

[26] A. M. E. Bortolanza and A. Balça. Perfil leitor de universitários ingressantes em um curso de formação de professores. In M. L. Chaleta et al. (Coord.) Actas da "Il international conference learning and teaching in higher education" and "Learning orchestration in higher education." Évora: Gabinete para a Promoção do Sucesso Académico. Évora: Universidade de Évora, 279-296, 2013. Retrieved from http://dspace.uevora.pt/rdpc/bitstream/10174/9740/1/LTHE_2013CD_AtasVersaoFINAL.pdf

[27] M. T. Trisciuzzi. "Image and imagination in education. visual narrative through children's literature." Ricerche di Pedagogia e Didattica. Journal of Theories and Research in Education no. 12, (3), 69-81, 2017.

[28] F. B. Ramos and M. F. Nunes. "Efeitos da ilustração do livro de literatura infantil no processo de leitura." Educar em Revista, no.48, 251-263, 2013.

[29] F. Azevedo. Clássicos da literatura infantil e juvenil e a educação literária. Guimarães: Opera Omnia, 2013.

[30] N. K. Duke and P. D. Pearson. Effective practices for developing reading comprehension. In A. E. Farstrup \& S. J. Samuels (Eds.), What research has to say about reading instruction (3rd ed., pp. 205-242). Newark, DE: International Reading Association, 2002.

[31] N. K. Duke, P. D. Pearson, S. L. Strachan and A. K. Billman. Essential elements of fostering and teaching reading comprehension. In S. J. Samuels \& A. E. Farstrup (Eds.), What research has to say about reading instruction (4th ed., pp. 51-93). Newark, DE: International Reading Association, 2011.

[32] J. L. P. Vaz. "O ensino da compreensão para uma leitura mais eficaz." EXEDRA, no.9, 161-174, 2010. Retrieved from http://www.exedrajournal.com/docs/02/15-JoaoVaz.pdf

[33] H. A. Welker. H. A. "Pesquisando o uso de dicionários." Linguagem \& Ensino, no.9 (2), 223-243, 2006. Retrieved from www.rle.ucpel.tche.br/index.php/rle/article/download/172/139

[34] I. Vázquez, I. "O papel do dicionário no ensino e aprendizagem das línguas." EXEDRA, no.9, 107-110, 2010. Retrieved from http://www.exedrajournal.com/docs/02/09\%20\%20lgnacio\%20Vasquez.pdf

[35] O. C. Sousa. O texto literário na escola: uma outra abordagem - círculos de leitura. In F. Azevedo (Coord.). Formar leitores: das teorias às práticas (pp. 45-68), 2007. Lisboa: LIDEL.

[36] I. Solé. "Competencia lectora y aprendizaje." Revista Iberoamericana de Educación, no.59, 43-61, 2012. Retrieved from http://www.rieoei.org/rie59a02.pdf

[37] I. Sim-Sim. O ensino da leitura: a compreensão de textos. Lisboa: Direção Geral de Inovação e Desenvolvimento Curricular, 2007.

[38] V. Tompkins, Y. Guo and L. M. Justice. "Inference generation, story comprehension, and language skills in the preschool years." Reading and Writing, no.26 (3), 403-429, 2013. doi10.1007/s111-012-9374-7 
[39] Sá, C. M. (2014). Estratégias do leitor. Aveiro: Universidade de Aveiro/Departamento de Didática e Tecnologia Educativa [documento policopiado].

[40] N. K. Duke and P. D. Pearson. Effective practices for developing reading comprehension. In A. E. Farstrup \& S. J. Samuels (Eds.), What research has to say about reading instruction (3rd ed., pp. 205-242). Newark, DE: International Reading Association, 2002.

[41] A. Wigfield, J. Gladstone and L. Turci. "Beyond cognition: reading motivation and reading comprehension." Child Development Perspectives, no.10, (3), 190-195, 2016. https://doi.org/10.1111/cdep.12184. 